\section{Using Flipped Classroom and Virtual Field Trips to Engage Students}

\author{
Kent D. Kobayashi ${ }^{1}$
}

\begin{abstract}
AdDitional INDEX wORDs. active learning, pedagogy, undergraduate, horticulture, agriculture

SUMMARY. Student engagement in the classroom is critical for effective learning. To enhance student engagement, several teaching approaches can be used, including a flipped classroom approach and virtual field trips. The flipped classroom approach was used in an undergraduate tropical production systems course in which students viewed lecture materials outside of class, brought their smart devices to class to review materials, searched for new information on the Internet, and participated in small group discussions. In the virtual field trip assignment, each student visited a commercial farm or nursery, interviewed the owner or manager, and gave a presentation to the class about the operation of the enterprise and its sustainable practices.
\end{abstract}

$\mathrm{I}$ n a typical university classroom, students hear a lecture and take notes. They then work on homework, projects, and other activities outside of class (Talbert, 2012). In the flipped classroom, instead of simply receiving information from the instructor during class, students review information pertaining to concepts outside of class and come to class prepared to discuss these concepts (Kharbach, 2012; Young, 2011). Studies have shown that the flipped classroom approach can help improve student learning (Moravec et al., 2010). The flipped classroom approach can be enhanced by having students bring a laptop, tablet, or smartphone to class, where these devices become an integral part of inclass activities such as reviewing assigned materials, sharing information with other students, and searching for new and supplemental resources on the Internet.

Field trips play an important role in horticultural courses. Well-planned field trips benefit students by connecting in-class studies with real world situations (Klemm and Tuthill, 2003). However, instructors sometimes face instructional and logistical

\footnotetext{
Tropical Plant \& Soil Sciences Department, University of Hawaii at Manoa, 3190 Maile Way, St. John 102, Honolulu, HI 96822

This article was part of the workshop "Five-minute Impact Strategies for Engaging Students-Where to Start with Service-learning and Fundraising?" held on 4 Aug. 2015 at the ASHS Annual Conference, New Orleans, LA, and sponsored by the Teaching Methods (TCHG) Working Group.

${ }^{1}$ Corresponding author. E-mail: kentko@hawaii.edu.
} doi: 10.21273/HORTTECH03350-17 constraints that can hinder their planning and conducting of actual field trips (Harkess et al., 2007). An alternative is the virtual field trip, which is a computer-based, multimedia simulation of actual field trips (Clark et al., 2002). Virtual field trips can be stand alone and used in place of actual field trips, be used to help students prepare ahead of an actual field trip (Bellan and Scheurman, 2001), or be used to focus classroom discussion after an

The objective of this article is to discuss how implementing a flipped classroom approach and virtual field trips were used to foster student engagement in an undergraduate Tropical Plant \& Soil Sciences (TPSS) course at the University of Hawaii (TPSS 300 Tropical Production Systems) since 2008 .

\section{TPSS 300}

The required course TPSS 300 for TPSS undergraduate students is offered each spring semester. This four-credit course includes three 1 -h lecture sessions and a 3-h laboratory period each week. The TPSS 300 course typically consists of sophomores to seniors from TPSS, although students from majors in the College of Tropical Agriculture and Human Resources (Natural Resources and Environmental Management, and Molecular Biosciences and Bioengineering) and outside the college (Marketing, Management, and English) have enrolled. The course was created in 1997 with my teaching it since 2008. Student enrollment has actual field trip is completed. ranged from a minimum of 6 (2016) to maximum of 24 (2013), with an average of 14 students.

\section{Flipped classroom approach}

The flipped classroom approach was implemented in TPSS 300 to introduce more student centered active learning to supplement lectures. Students read and viewed assigned videos, publications, websites, and other resources outside of class. Then, in class, students participated in small groups discussions about what they had read and viewed, answered assigned questions, and reported the answers to the class. Students brought their smart devices to class to review assigned videos and websites and do supplemental Internet searches for relevant information for group and class discussions and hands-on activities.

YouTube (San Bruno, CA) videos, websites, handouts, popular works publications, scientific articles, and online computer models and simulations were assigned to be viewed outside of class. The instructor spent time locating and evaluating videos and websites to be sure that they were appropriate for the students and provided information that would have been covered by lectures. Videos were brief, 3-5 $\mathrm{min}$, to maintain student interest with 10-15 min being the upper limit. Websites included HortiBiz, Perennial Pulse, and Urban Ag News. Handouts covered terminology for systems analysis, growth analysis, and yield-component analysis. Grower Talks, Greenhouse Grower, and Hawaii Landscape were some of the popular works publications, and scientific articles of various lengths were chosen from different journals such as HortTechnology, Acta Horticulturae, and Scientia Horticulturae. Online models and simulations, Wheat Yield Potential Calculator and The Ohio State Phenology Calendar, provided students with hands-on simulation experience.

In-class quizzes and assignments were used to ensure that students had read and viewed the assigned materials outside of class. After forming into groups of two to four students, each group was given a separate set of questions to discuss and answer in class. Students discussed the materials they had viewed or read, answered the assigned questions, and reported the 
answers to the class via short presentations. Students were required to bring their laptops, tablets, or smartphones to class to aid in discussions and hands-on activities. Although bring your own device does not necessarily need to be part of the flipped classroom approach, the devices were useful and supported in-class learning activities. They facilitated group viewing of videos, group discussions and answering of questions, and searching the internet for additional information to make group decisions.

Small group discussions and inclass activities provided each student an opportunity to speak and share their personal experiences. For example, in 2016, there were two students from the United States mainland who grew up on family farms that were greater than 1000 acres (404.7 ha) each. Contrast this with the average coffee (Coffea arabica) or papaya (Carica papaya) farm in Hawaii being only 6 acres $(2.4$ ha). As the semester progressed, students appeared more poised when speaking within groups and in front of the class.

The flipping classroom approach was gradually introduced into the course over several years and changed the course from a lecture course to one with more active learning and small group discussions. Initially, lecturing was the primary teaching method. Later, the flipping classroom approach was periodically introduced by assigning students to view outside of class relevant videos, websites, and reading materials. This helped reduce the number of lectures and lecture preparation time for the instructor, and the flipped classroom approach became the predominant teaching technique. More time was devoted to developing relevant in-class activities to enhance student learning. The preclass makeup was the use of lecturing by the instructor and guest speakers. As the flipped classroom approach was introduced and used more in class, the amount of lecturing was reduced. As an example of the postclass makeup was instead of a lecture on different cropping systems, students would view outside of class six videos of examples of different cropping systems use by different farms. In class, students would form groups of two to four students, select a video, and discuss several questions about that video. Then, the group would go to the front of the class, and each student would have the opportunity to answer a question about the video. The class would ask questions of the group about the video, and similarly the group members would ask the class questions. In the Spring 2013 course evaluation, a student responded to the question "What did you find most valuable and helpful about this course?" with "I found most valuable the manner in which the material was presented hands on, outside of class room, via internet, discussion, presentation repetitively too using different examples to identify with and help me to remember."

\section{Virtual field trips}

Since first taught in 1997, TPSS 300 has had live, traditional field trips during its 3-h laboratory session. However, student course evaluations of TPSS 300 indicated that students were not satisfied with the course, particularly with the duplication of TPSS 300 field trip visits with those of other TPSS courses. On my first teaching of the course in 2008, to address the duplication of visits, different sites were selected for actual field trips, and the use of virtual field trips was implemented (Kobayashi and Perez, 2009).

The intent of the virtual field trip assignment was for each student to design an oral presentation as if the whole class was going on a field trip. Each student chose and visited a commercial farm or nursery, interviewed the owner or manager, took pictures, and learned about the operations of the enterprise. It was the student's responsibility to select a farm or nursery, contact the owner, and arrange transportation to the farm/nursery. They needed to ask permission if taking pictures was allowed; if not, then that farm/nursery could not be used for the assignment. Once a farm/nursery was selected, no other student could choose it for his or her assignment. Using PowerPoint (Microsoft Corp., Redmond, WA), each student gave a presentation on the enterprise in class and submitted a written report.

When students create their own virtual field trips, their attention and learning is focused on the intricate aspects of the operation and how it is presented (Clark et al., 2002). A oneon-one visit allowed the owner to show the student production areas that would be restricted in a large group tour, such as a restricted area of a greenhouse or working in an aseptic tissue culture transfer hood. Student presentations were an alternative to guest lectures by an owner or manger about their business. Students became aware of more farms/nurseries than would have been possible through actual field trips during the semester. The virtual field trip assignment allowed students to select businesses they were interested in learning more about. Instead of selecting some of the larger well-known farms and nurseries that were visited in other TPSS courses, students selected smaller farms and nurseries that were not known to the instructor or most of the other class members. In the Spring 2015 course evaluation, two students responded to the question "ten years from now I'll probably remember this course most by" with "I will remember the virtual field trips" and "Learning what virtual field trips are."

\section{Conclusions}

Using a flipped classroom approach and virtual field trips in TPSS 300 increased active learning and teamwork. They helped to foster student engagement through various activities - small group discussions in which students viewed videos together, answered questions individually within a group, and searched the internet on topics the group was interested in. Visiting a farm or nursery of their interest engaged the student directly with the owner and gain firsthand experience on its operations.

\section{Literature cited}

Bellan, M.J. and G. Scheurman. 2001. Actual and virtual reality: Making the most of field trips, p. 154-162. In: R.L. Stevens (ed.). Homespun: Teaching local history in grades 6-12. Heinemann, Portsmouth, NH.

Clark, K.F., A. Hosticka, M. Schriver, and J. Bedell. 2002. Computer based virtual field trips. Proc. ED-MEDIA 2002 World Conf. Educational Multimedia, Hypermedia \& Telecommunications. Assn. Advancement Computing Educ., Norfolk, VA.

Harkess, R.L., J.S. Kuehny, M.R. Evans, L. Greer, and T. Cavins. 2007. Virtual 


\section{WORKSHOP}

field trips: Expanding the greenhouse classroom. Acta Hort. 762:439-443.

Kharbach, M. 2012. Flipping the classroom simply explained. 19 Aug. 2016. <http://www.educatorstechnology. com/2013/09/flipping-classroomsimply-explained.html>.

Klemm, E.B. and G. Tuthill. 2003. Virtual field trips: Best practices. Intl. J. Instr. Media 30:177-193.
Kobayashi, K.D. and K. Perez. 2009. Enhanced active learning and TA involvement in a production systems horticulture course. Proc. 2009 Hawaii Intl. Conf. Educ.-Conf. Proc. p. 738-748.

Moravec, M., A. Williams, N. AguilarRoca, and D.K. O'Dowd. 2010. Learn before lecture: A strategy that improves learning outcomes in a large introductory biology class. CBE Life Sci. Educ. 9:473481 .

Talbert, R. 2012. Inverted classroom. Colleagues 9:1-2.

Young, B. 2011. 7 Things you need to know about flipping the classroom. 20 Aug. 2016. <http://tlt.psu.edu/wpcontent/uploads/sites/7104/2011/ 09/2011-Flipping-the-Classroom.pdf $>$. 